\title{
ÜZEMANYAG BIOKOMPONENSEK ELŐÁLLÍTÁSÁHOZ TERMESZTETT MIKROALGÁK FELDOLGOZÁSAKOR KELETKEZŐ MELLÉKÁRAMOK HASZNOSÍTÁSI LEHETŐSÉGEI
}

\section{UTILIZATION OF BYPRODUCTS FROM ALGAE BIOMASS THAT CULTIVATED FOR BIOFUEL PRODUCTION}

\author{
Bocsi Róbert ${ }^{1}$, Rippelné Pethő Dóra ${ }^{2}$, Horváth Géza ${ }^{3}$, Hodai Zoltán ${ }^{4}$, Bobek Janka ${ }^{5}$ \\ Pannon Egyetem, Mérnöki Kar, Vegyészmérnöki-és Folyamatmérnöki Intézet, Ve- \\ gyipari Müveleti Intézeti Tanszék, H-8200 Magyarország, Veszprém, Egyetem u. 10. \\ Telefon: +36-88-624-000, 6181 \\ Ibocsirobert@almos.uni-pannon.hu \\ 2pethod@almos.uni-pannon.hu \\ 3horvathg@almos.uni-pannon.hu \\ 4hodaiz@almos.uni-pannon.hu \\ 5bobekj@almos.uni-pannon.hu
}

\begin{abstract}
Carbon dioxide is the primary greenhouse gas emitted through human activities. There are natural bioprocesses where this molecule is converted into biomass. With cultivation of microalgae we can feed back the carbon content of $\mathrm{CO}_{2}$ into biological systems and we can get numbers of valuable organic compounds, among others biofuel, to reach ecological and economical benefits. However we should take care of recycling byproducts as it possible.
\end{abstract}

Keywords: microalgae, cultivation, byproducts recycle

\section{Összefoglalás}

A természetben müködnek olyan spontán folyamatok, amelyeket alapul véve a kibocsátásra váró $\mathrm{CO}_{2}$ széntartalmát biológiai rendszerbe visszavezethetjük, ezáltal számos értékes termék nyerhető, akár üzemanyag biokomponensek is. Egy algatechnológiai rendszer üzemeltetése során ezek a vegyületek elöállíthatók, ugyanakkor tekintettel kell lennünk arra, hogy feldolgozási lépések során olyan müveleteket alkalmazzunk, amelyekkel elérhető, hogy a termék által hátrahagyott ökológiai lábnyom a lehető legkisebb legyen. A megtermelt alga feldolgozása során tehát a keletkező hulladékok mennyiségét a lehető legkisebbre kell szorítanunk és azok újrahasznosításáról gondoskodnunk kell.

Kulcsszavak: mikroalga, termesztés, melléktermékek, újrahasznositás 


\section{A mikroalgák termesztése}

A fotoszintetizáló élölények a növekedésükhöz, szaporodásukhoz $\mathrm{CO}_{2}$-ot használnak fel, melynek átalakításához szükséges energiát napfényből nyerik. A lipidtermelésre használt mikroalgák a szervezetük felépítéséhez szükséges anyagokat vizes oldatból veszik fel.

A megfelelő algatermesztő rendszer kialakításához sorra kell venni, melyek a termesztésbe bevonható fajok és mely paraméterek befolyásolják az algák fejlödését. A termesztési paraméterek helyes megválasztása alapvetően befolyásolja a teljes folyamat sikerességét.

\subsection{A mikroalgák hasznosítása}

Algákból számos terméket állíthatunk elö, melyek közül üzemanyag előállításra elsősorban a lipidek a megfelelő vegyületek. A lipidek számos alkalmazásban elöfordulnak. Tisztítás, ill. átalakítás után kozmetikai cikkek, élelmiszerek összetevői vagy akár motorhajtóanyagok biokomponensei is lehetnek.[1]

\subsection{A mikroalgák termesztése}

Energetikai célokra azok az akár édesvízi-, akár tengeri algafajok alkalmasak, amelyek a termesztési periódus alatt tömegük minél nagyobb hányadát lipidekké alakítják. Ezek a lipidek átalakítás után motorhajtóanyagok biokomponensei lehetnek. [2] Fontos megjegyezni, hogy a termesztési periódus alatt elért biomassza-koncentrációra és lipid-tartalomra megadott értékek a termesztési technika, a környezeti valamint az ésszerủen szabályozható müködési paraméterek függvényében jelentős különbségeket mutatnak.

$\mathrm{Az}$ energiatermelésre használt mikroalgák a szervezetük felépítéséhez szükséges anyagokat vizes oldatból veszik fel. Egyrészt a tápoldatban lévő szervetlen sókat, egyszerü szerves vegyületeket, másrészt a reaktortérbe juttatott $\mathrm{CO}_{2}$-ot, hidro- génkarbonát formájában. Míg előbbieket bizonyos szennyvizekböl pótolni lehet, addig a szén-dioxid forrása lehet füstgáz, de származhat egyéb technológiákból is.

\section{A mikroalgák feldolgozása}

Az algatermékek kinyerésének két szükséges lépése van. $\mathrm{Az}$ egyik az algaszuszpenzió sürítése, a másik pedig az értékes komponensek kinyerése.

\subsection{A szuszpenzió sưrítése}

$\mathrm{Az}$ algaszuszpenzió sủrítésekor keletkező oldat föként azokat a szervetlen sókat tartalmazza, amelyek az algák termesztéséhez egyébként is szükségesek, ugyanakkor a termesztés során keletkező metabolitok is jelen vannak benne.

A tápoldatból a termesztés során a legnagyobb mennyiségben a makrokomponensek fogyására lehet számítani (nitrogén-, foszfor- és a kálium-forrás).

Ha olyan feldolgozási müveletet tudunk alkalmazni, amely során vegyszer adagolása nem szükséges, például szürés, centrifugálás vagy membránszeparációs múveletek, akkor a keletkező oldat a szükséges tápkomponensekkel való kiegészítés után a termesztéshez többször újra felhasználható.

Amennyiben a sürítéshez valamilyen vegyszer adagolása válik szükségessé, akkor meg kell vizsgálni, hogy milyen feltételek mellett hasznosítható maga a termék és a mellékáram is. Például, ha flokkuláló szerként vas(III) ionokat tartalmazó oldatot is használunk, akkor nem csak a visszaforgatásra kerülő folyadék vaskoncentrációját kell az algák számára toxikus koncentráció alá csökkenteni, hanem arra is figyelemmel kell lenni, hogy az extrakció mellékáramainak felhasználása emiatt lehetséges marad-e.

A termesztésbe a sürítési müveletekből visszavezetett áramok esetében a recirkulációs körök számát nem csak a hozzáadott vegyszerek befolyásolhatják, hanem a körönként esetlegesen dúsuló metabolitok jelenléte is. 


\subsection{A mikroalgák közvetlen felhaszná- lása}

A sürítési műveletek során elöállított algatermék közvetlenül is felhasználásra kerülhet. A legismertebb ezek közül az emberek számára élelmezési céllal valamint az állati takarmányként való felhasználás. Ez főként szárított alga fogyasztását jelenti annak telítetlen zsírsav, astaxantin vagy béta-karotin tartalma miatt.[3]

A másik jelentős közvetlen felhasználási mód a növényi tápként való alkalmazás. Az algából (pl. Spirulina platensis) nyert sürítményt közvetlenül levéltrágyaként a növények növekedésére előnyös hatás érhető el. Ugyanakkor az ilyetén célú felhasználás esetén az algatermesztés feltételei az előbb említett lehetőséggel szemben sokkal kevésbé igényel speciális feltételeket, bizonyos típusú szennyvizek alkalmazása is megengedett.[4]

További lehetőség a közvetlen hasznosításra a hidrotermális katalitikus algafeldolgozás, mely során a mikroalga szuszpenziót magas hőmérsékleten $\left(300^{\circ} \mathrm{C}\right.$ felett), nagy nyomáson (100 bar felett) katalizátor jelenlétében inert környezetben kezelik. A feldolgozás során föként energiarecirkulációra van lehetőség, ugyanakkor a kapcsolódó szétválasztó rendszerben kinyert olaj mellett a katalizátor és a vizes fázis egy részének visszanyerése is megtörténhet.[5]

\subsection{A biomassza extrakciója}

Az algaolaj extrakciója két különböző stratégia szerint végezhetö. Az egyik, hogy a nedves vagy szárított algamasszából közvetlenül kinyerjük a lipideket, a másik, hogy az extrakciót sejtfeltárás előzi meg.

A mikroalga extrakcióját kiegészítő lépésként megelözheti egy vegyszeres kezelés, amely a sejtfalon belül felhalmozott értékes komponensek hozzáférhetőségét biztosítja. Ezeknek a kezeléseknek a célja az, hogy vagy közvetlen vegyszeres keze- léssel, vagy pedig a sejtek környezetének tulajdonságait úgy változtassák, hogy a sejtfal integritása megszünjön. E módszerek esetében az alkalmazott vegyszer miatt egy közbülső szeparációs lépést kell végrehajtani az extrakció elött, de az algaszárítás energiaigényének egy része így megtakarítható.[6]

A szárított alga-biomassza extrakciójához olyan specifikus oldószert érdemes választani, amelynek jelenléte mellett a termék közvetlenül felhasználható.

A legkecsegtetőbb megoldás a szuperkritikus fluidumok használata, melynek során az oldószer a müvelet végrehajtását követően csak nyomokban fordul elö. Például az algák szupekrtikus széndioxiddal történő extrakciója során az expandált oldószer sem a raffinátumban, sem az extraktumban nem található meg.[7]

Ilyen lehet például a színanyagok extrakciója etanollal, melynek során a tinktúra gyakorlatilag közvetlenül felhasználásra kerülhet.

Amennyiben az alapanyagból indokolt egy lépésben az értékes komponenseket egy szélesebb spektrumú oldószer eleggyel kinyerni, a komponensek visszanyerése és a azok egymástól való elválasztása során további mellékáramok keletkezésére lehet számítani. Ilyen lehet például a Bligh-Dyer féle extrakciós módszer, melynek során kloroform és metanol elegyével valósítják meg a poláris és az apoláris lipidek kinyerését. A kapott extraktumot ez után osztják meg két fázis között, amelyek polaritása a kinyerhető komponensek jellegét meghatározza. [8]

Ebben a szétválasztási lépésben az oldószer kiválasztásánál az is jelentős szerephez juthat, hogy a raffinátumban az oldószer maradékának jelenléte a további hasznosítást befolyásolja-e.

A raffinátum egyik felhasználási lehetösége a biogáz előállítás. A kiextrahált biomassza számos olyan komponenst, szénhidrátokat, mikroelemeket, tartalmaz, amelyek 
az anaerob lebontás esetén jól hasznosulhatnak. Ugyanakkor a lehetnek olyan tulajdonságai a raffinátumnak, amelyek annak ilyetén felhasználását nehezítik. Ezek nem csak a fermentáció sikerességét befolyásoló tényezők lehetnek (lúgosság, vastartalom), hanem ezek biogáz iszapban történő dúsulása miatt is jelentőséggel bírhatnak.

\section{Következtetések}

Bármilyen egyszerű szervezetek is a mikroalgák, az előállításuk és a feldolgozásuk során a gazdasági a technológiai célok mellett az is fontos szereppel bír, hogy ezt az értékes alapanyagot a lehető legnagyobb mértékben felhasználjuk.

Az algák feldolgozásával sokféle termék nyerhető (üzemanyagok biokomponensei, élelmiszeripari alapanyagok, étrend-kiegészítők, gyógyszerek), melyek előállítása során kellő körültekintéssel számos mellékáramot újra hasznosíthatunk vagy azok keletkezését megelőzhetjük.

\section{Szakirodalmi hivatkozások}

[1] Wang, B., Y. Li, N. Wu, and C. Q. Lan: $\mathrm{CO}_{2}$ bio-mitigation using microalgae. Applied
Microbiology and Biotechnology 79(5): 707718. . (2008.)

[2] Chisti, Y.: Biodiesel from microalgae. Biotechnology Advances 25(3): 294-306. (2007.)

[3] M. Vigani et al.. Food and feed products from micro-algae: Market opportunities and challenges for the EU Trends in Food Science \& Technology 42 (2015) 81-92

[4] S.C. Wuang et al.: Use of Spirulina biomass produced from treatment of aquaculture wastewater as agricultural fertilizers, Algal Research 15 (2016) 59-64

[5] E.P. Bennion et al.: Lifecycle assessment of microalgae to biofuel: Comparison of thermochemical processing pathways Applied Energy 154 (2015) 1062-1071

[6] A. Sathish, R.C. Sims: Biodiesel from mixed culture algae via a wet lipid extraction procedure, Bioresource Technology 118 (2012) 643-647

[7] S.P. Jeevan Kumar et al.: Sustainable green solvents and techniques for lipid extraction from microalgae: A review, Algal Research 21 (2017) 138-147

[8] E. Santillan-Jimenez et al.: Extraction, characterization, purification and catalytic upgrading of algae lipids to fuel-like hydrocarbons, Fuel 180 (2016) 668-678 